\title{
Association of Angiotensin-Converting Enzyme Intron 16 Insertion/Deletion and Angiotensin II Type 1 Receptor A1166C Gene Polymorphisms with Preeclampsia in South East of Iran
}

\author{
Saeedeh Salimi, ${ }^{1,2}$ Mojgan Mokhtari, ${ }^{3}$ Minoo Yaghmaei, ${ }^{3}$ \\ Mohammad Jamshidi, ${ }^{2}$ and Anoosh Naghavi ${ }^{1,4}$ \\ ${ }^{1}$ Cellular and Molecular Research Center, Zahedan University of Medical Sciences, Zahedan, Iran \\ ${ }^{2}$ Department of Biochemistry, School of Medicine, Zahedan University of Medical Sciences, Zahedan, Iran \\ ${ }^{3}$ Department of Obstetrics and Gynecology, School of Medicine, Zahedan University of Medical Sciences, Zahedan, Iran \\ ${ }^{4}$ Department of Microbiology, School of Medicine, Zahedan University of Medical Sciences, Zahedan, Iran
}

Correspondence should be addressed to Anoosh Naghavi, anooshnaghavi@yahoo.com

Received 26 February 2011; Accepted 4 June 2011

Academic Editor: Saulius Butenas

Copyright (c) 2011 Saeedeh Salimi et al. This is an open access article distributed under the Creative Commons Attribution License, which permits unrestricted use, distribution, and reproduction in any medium, provided the original work is properly cited.

\begin{abstract}
Some evidence suggests that a variety of genetic factors contributed in pathogenesis of the preeclampsia. The aim of this study was to assess the association between the angiotensin-converting enzyme (ACE) I/D and angiotensin II type1 receptor A1166C polymorphisms with preeclampsia. This study was performed in 125 preeclamptic pregnant women and 132 controls. The I/D Polymorphism of the ACE gene was assessed by polymerase chain reaction and the A1166C Polymorphism of the AT1R gene was determined by restriction fragment length polymorphism. The genotype and allele frequencies of I/D polymorphism differed between two groups. The risk of preeclampsia was 3.2-fold in pregnant women with D allele (OR, 3.2 [95\% CI, 1.1 to 3.8]; $P=0.01)$. The distribution of the AT1R gene A1166C polymorphism was similar in affected and control groups. Our results supported that presence of the I/D polymorphism of ACE gene is a marker for the increased risk of preeclampsia.
\end{abstract}

\section{Introduction}

Preeclampsia is a potentially serious condition of pregnancy that covers almost $10 \%$ of pregnancies in the developing countries. It has a severe morbidity and mortality risk for both mother and child [1]. The exact etiology of this disease is still unknown but several pathophysiological mechanisms have been suggested for preeclampsia. These include endothelial dysfunction, inflammatory pathway, oxidative stress, activation of thrombosis, and the renin-angiotensin system [2].

Various genetic and environmental factors have been known that contribute in pathogenesis of this disorder [3]. Ward and Lindheimer reported an incident risk of 20 to 40 percent for daughters of preeclamptic mothers, 11 to 37 percent for sisters of preeclamptic women, and 22 to 47 percent in twin studies for preeclampsia [4]. Several studies have tried to demonstrate or refute the role of rennin angiotensin system genes as candidates for the development of preeclampsia. The circulating renin-angiotensin system (RAS) is an important pathway that regulates blood pressure and electrolyte balance [1].

In low blood pressure and low circulating sodium chloride, the renin enzyme synthesized by juxtaglomerular cells of the afferent renal arterioles of kidney and released in blood [5]. Renin cleaves angiotensinogen, to angiotensin-1 (ANG I), a ten-amino-acid peptide. ANG I is an inactive peptide but is cleaved by angiotensin-converting enzyme (ACE) to the biologically active angiotensin-II ( 8 amino acid). The angiotensin converting enzyme (ACE; EC 3.4.15.1) is a dipeptidyl carboxypeptidase that is encoded by the ACE gene. This gene is located on chromosome $17 \mathrm{q} 23$ and contains 26 exons and 25 introns [6]. Two isoforms of angiotensin receptors exist in different tissues: AT1 and AT2. They are from seven transmembrane G-protein-coupled receptor family. ANG II exerts most of its effects via the 
activation of AT1 receptors which are expressed in vascular smooth muscle cells and adrenal glands, among others. This receptor is coupled to the Gq protein to increase intracellular calcium [5].

Therefore we investigated the relationship of two common polymorphisms of the rennin-angiotensin system: intron 16 of the ACE gene on chromosome 17 and the A-to$\mathrm{C}$ polymorphism in the $3^{\prime}$ untranslated region at nucleotide 1166 of the AT2R1 gene on chromosome 3.

\section{Materials and Methods}

2.1. Study Subjects. The project was approved by the Zahedan University of Medical Sciences Ethics Committee. This cross-sectional study was performed in 125 preeclamptic pregnant women and 132 healthy pregnant women from January 2008 to February 2010. At the time of admission, after written consent a verbal interview was conducted to determine maternal age, gestational age, gravidity, birth weight, family history of preeclampsia, history of preeclampsia in previous pregnancies, and ethnicity. Ethnicity was determined by self report. Preeclampsia was defined as increased blood pressure $(\geq 140 \mathrm{mmHg}$ systolic or $\geq 90 \mathrm{mmHg}$ diastolic on 2 or more measurements at least $6 \mathrm{~h}$ apart) and with significant proteinuria $\geq 0.3 \mathrm{~g} / 24 \mathrm{~h}$ or $\geq+1$ on a urine dipstick in a woman after 20 weeks of gestation [7].

Blood pressure was taken with the patient in an upright position, after a 10-minute rest period with a mercury sphygmomanometer. The right arm was used for the measurement, and it was placed in a horizontal position at heart level [8].

Exclusion criteria included twin or multiple pregnancies or any evidence of previous medical disease. One hundred thirty seven normotensive pregnant volunteers were randomly recruited from the Obstetrics ward of Ali-EbneAbitaleb Hospital who did not have any evidence of previous medical illness.

2.2. DNA Analysis. Genomic DNA was extracted from peripheral blood leukocytes by DNA isolation kit (Roche, Germany). Two oligonucleotide primers, forward: $5^{\prime}$-CTG GAG AGC CAC TCC CAT CCT TTC T- $3^{\prime}$ and reverse: $5^{\prime}$ GGG ACG TGG CCA TCA CAT TCG TCA G-3' based on the flanking sequences of the insertion/deletion region on the intron 16 of ACE gene were used to amplify the corresponding DNA fragments by polymerase chain reaction (PCR) [9]. The reaction was performed in a $25-\mu \mathrm{L}$ final volume and contained $25 \mathrm{pmol}$ of each primer, $0.1 \mathrm{mmol}$ of each deoxynucleoside triphosphate (Fermentas, Lithuania), $1 \mathrm{U}$ Taq DNA polymerase (Fermentas, Lithuania), $50 \mathrm{mmol} / \mathrm{L}$ $\mathrm{KCl}, 1.5 \mathrm{mmol} / \mathrm{L} \mathrm{MgCl}_{2}, 10 \mathrm{mmol} / \mathrm{L}$ Tris- $\mathrm{HCl}(\mathrm{PH}=8.3)$, and $200 \mathrm{ng}$ of genomic DNA according to the protocol as previously described except for the annealing step which was at $60^{\circ} \mathrm{C}$ [10]. The PCR products of two alleles of 490 and $190 \mathrm{bp}$ were electrophoresed in $2 \%$ agarose gels and visualized by ethidium bromide staining. Due to the $\mathrm{D}$ allele in heterozygous samples which are preferably proliferated, every sample demonstrated to have DD genotype depending on a second, independent PCR amplification with a major pair known as an addition which is particular sequence described before. The feedback produced a 335-bp amplicon just in the existence of an I allele and no product in homozygous for DD [9].

For detection of A1166C polymorphism of the angiotensin II receptor AT1, two oligonucleotide primers (forward) $5^{\prime}$-AAT GCT TGT AGC CAA AGT CAC CT-3' and (reverse) $5^{\prime}$-GGC TTT GCT TTG TCT TGT TG-3' were used for amplification the corresponding DNA fragment by the polymerase chain reaction [11]. The reaction was performed in a $25-\mu \mathrm{L}$ final volume and contained $30 \mathrm{pmol}$ of each primer, $0.1 \mathrm{mmol}$ of each deoxynucleoside triphosphate (Fermentas, Lithuania), $1 \mathrm{U}$ Taq DNA polymerase (Fermentas, Lithuania), $50 \mathrm{mmol} / \mathrm{L} \mathrm{KCl}, 2.5 \mathrm{mmol} / \mathrm{L} \mathrm{MgCl} 2,10 \mathrm{mmol} / \mathrm{L}$ Tris- $\mathrm{HCl}(\mathrm{PH}=8.3)$, and $250 \mathrm{ng}$ of genomic DNA according to the following protocol: initial denaturation at $94^{\circ} \mathrm{C}$ for $5 \mathrm{~min} ; 35$ cycles of denaturation at $94^{\circ} \mathrm{C}$ for $30 \mathrm{sec}$, annealing at $57^{\circ} \mathrm{C}$ for $30 \mathrm{sec}$, and extension at $72^{\circ} \mathrm{C}$ for $1 \mathrm{~min}$ and $30 \mathrm{sec}$; and final extension at $72^{\circ} \mathrm{C}$ for $5 \mathrm{~min}$. The $856 \mathrm{pb}$ PCR fragments were digested with Dde1 restriction enzyme (Fermentas, Lithuania) for $16 \mathrm{~h}$ at $37^{\circ} \mathrm{C}$. The wild-type allele (A allele) has one Dde1 cleavage site and digested to 600 and $256 \mathrm{bp}$ fragments, whereas the mutant allele ( $\mathrm{C}$ allele) has two Dde1 cleavage site and $256 \mathrm{bp}$ fragment is cleaved to 146 and $110 \mathrm{bp}$ fragments too. Digested samples were separated by electrophoresis on a $2 \%$ agarose gel and visualized by ethidium bromide staining.

2.3. Statistical Analyses. All statistical analyses were performed with SPSS V-11.5. The differences between groups were examined by $\chi^{2}$ test or an independent Student's $t$ test whenever appropriate. Allele frequencies were estimated by the gene counting method. The frequencies of the alleles and genotypes were compared between patients and control groups by the $\chi^{2}$ test when appropriate. The odds ratio (OR) and 95\% confidence intervals (CI) were also estimated. The $\chi^{2}$ test was used for deviation of genotype distribution from Hardy-Weinberg equilibrium. Logistic regression analysis was employed to determine the relations of gene polymorphisms and other risk factors with preeclampsia.

\section{Results}

For the case control study, 125 preeclamptic women and 132 healthy pregnant women were enrolled the clinical and biochemical parameters of the controls and preeclamptic subjects are shown in Table 1.

There was no significant difference between two groups for maternal age and family history of preeclampsia.

As expected gestational age was significantly lower and systolic and diastolic blood pressure, primiparity, and history of preeclampsia were significantly higher in preeclamptic women. Although birth weight was lower in preeclamptic women, the difference was not significant.

The frequencies of ethnic groups (Persian, Balooch, and Afghan) were significantly different between preeclamptic women and controls $(P=0.03)$ and the risk of preeclampsia 
TABLE 1: Demographic characteristics of preeclamptic patients and controls.

\begin{tabular}{|c|c|c|c|c|c|}
\hline & $\begin{array}{l}\text { Preeclampsia } \\
\quad N=125\end{array}$ & $\begin{array}{l}\text { Controls } \\
N=132\end{array}$ & $\begin{array}{l}\text { Odds ratio } \\
(95 \% \mathrm{CI})\end{array}$ & $P$ value & $\chi^{2}$ \\
\hline Age (years) & $27.2 \pm 7.8$ & $26.2 \pm 6.2$ & & NS & \\
\hline Gestational age (days) & $256.2 \pm 25.4$ & $267.5 \pm 19.8$ & & 0.002 & \\
\hline Child birth weight (g) & $2789 \pm 829$ & $2955 \pm 646$ & & NS & \\
\hline Diastolic blood pressure (mm Hg) & $96 \pm 8.7$ & $69.2 \pm 8$ & & 0.0001 & \\
\hline Systolic blood pressure (mm Hg) & $151.7 \pm 14$ & $110.7 \pm 9$ & & 0.0001 & \\
\hline Primigravida $n(\%)$ & $56(45)$ & $42(32)$ & $1.7(1-2.9)$ & 0.025 & 4.4 \\
\hline Family history of preeclampsia $n(\%)$ & $47(38)$ & $42(32)$ & & NS & \\
\hline History of preeclampsia $n(\%)$ & $40(32)$ & $5(4)$ & $10.6(3.5-32)$ & 0.0001 & 23 \\
\hline Race $n(\%)$ & & & & 0.03 & 7.3 \\
\hline Persian & $32(26)$ & $49(37)$ & & & \\
\hline Balooch & $55(44)$ & $61(46)$ & & & \\
\hline Afghan & $38(30)$ & $22(17)$ & & & \\
\hline Persian + Balooch & $87(70)$ & $110(83)$ & $2(1.1-3.8)$ & 0.019 & 4.8 \\
\hline Afghan & $38(30)$ & $22(17)$ & & & \\
\hline
\end{tabular}

TABLE 2: Genotype and allele frequencies of I/D polymorphism of the ACE gene and A1166C polymorphism of the angiotensin II type-1 receptor in preeclamptic patients and controls.

\begin{tabular}{|c|c|c|c|c|c|}
\hline & $\begin{array}{c}\text { Preeclampsia } \\
\quad N=125\end{array}$ & $\begin{array}{l}\text { Controls } \\
N=132\end{array}$ & $\chi^{2}$ & $P$ value & Odds ratio \\
\hline \multicolumn{6}{|c|}{ I/D polymorphism } \\
\hline II, $n(\%)$ & $18(14.5)$ & $46(35)$ & & & \\
\hline ID, $n(\%)$ & $64(51.5)$ & $49(37)$ & & & \\
\hline $\mathrm{DD}, n(\%)$ & $43(34)$ & $37(28)$ & & & \\
\hline ID+DD (\%) & $107(85.5)$ & $86(65)$ & 14.4 & 0.0001 & $3.2(1.7-5.9)$ \\
\hline I ( $\%)$ & 0.4 & 0.53 & & & \\
\hline $\mathrm{D}(\%)$ & 0.6 & 0.47 & & & \\
\hline \multicolumn{6}{|c|}{ A1166C polymorphism } \\
\hline $\mathrm{AA}, n(\%)$ & $109(87)$ & $118(89)$ & & & \\
\hline $\mathrm{AC}, n(\%)$ & $15(12)$ & $12(9)$ & & & \\
\hline CC, $n(\%)$ & $1(1)$ & $2(2)$ & & & \\
\hline $\mathrm{AC}+\mathrm{CC}(\%)$ & $16(13)$ & $14(11)$ & 0.3 & 0.36 & \\
\hline $\mathrm{A}(\%)$ & 0.93 & 0.94 & & & \\
\hline $\mathrm{C}(\%)$ & 0.07 & 0.06 & & & \\
\hline
\end{tabular}

was twofold in Afghan women in contrast to Persian and Balooch women (OR, 2 [95\% CI, 1.1 to 3.8]; $P=0.01$ ).

Among the preeclamptic women, 20\% had early onset preeclampsia and $80 \%$ had late onset preeclampsia, also the frequency of severe and mild preeclampsia was $76 \%$ and $24 \%$, respectively.

Allele frequencies of I/D Polymorphism of ACE and A1166C polymorphism of angiotensin II type-1 receptor polymorphism were in Hardy Weinberg equilibrium in preeclampsia group however control subjects are in HardyWeinberg disequilibrium for both polymorphisms $(P=$ 0.004 and $P=0.02$, resp.).

The distribution of genotype and allele frequencies of I/D polymorphism of angiotensin-converting enzyme and A1166C polymorphism of angiotensin II type-1 receptor
(AT1R) gene were compared between preeclamptic patients and controls (Table 2).

The frequencies of II, ID, and DD genotypes were 14.5, 51.5 , and 34 percent in preeclamptic patients and 35,37 , and 38 in healthy pregnant women, respectively. The frequency of $\mathrm{D}$ allele was 0.6 in preeclamptic patients and 0.47 in controls. The risk of preeclampsia was 3.2-fold in pregnant women with D allele (ID+DD) in contrast to control women without D allele (OR, 3.2 [95\% CI, 1.1 to 3.8 ]; $P=0.01$ ).

The distribution of the AT1R A1166C polymorphism was similar in affected and control groups. The genotype frequencies for the control and preeclamptic women being 87,12 , and $1 \%$ and 89,9 , and $2 \%$ for the $\mathrm{AA}, \mathrm{AC}$, and CC genotypes, respectively. Only three subjects with the CC genotype were identified: two control subject and one subject 
TABLE 3: Multiple logistic regression analysis with forward stepwise selection (Wald).

\begin{tabular}{|c|c|c|c|c|c|c|c|c|}
\hline \multirow{2}{*}{ Risk factors } & \multirow{2}{*}{ B } & \multirow{2}{*}{ S.E. } & \multirow{2}{*}{ Wald } & \multirow{2}{*}{ df } & \multirow{2}{*}{ Sig. } & \multirow{2}{*}{$\operatorname{Exp}(B)$} & \multicolumn{2}{|c|}{$95 \% \mathrm{CI}$} \\
\hline & & & & & & & Lower & Upper \\
\hline Afghan race & 1.4 & 0.44 & 10.3 & 1 & 0.001 & 6.28 & 2.1 & 19 \\
\hline History of preeclampsia & 2.7 & 0.57 & 21.9 & 1 & 0.0001 & 14.7 & 4.8 & 45 \\
\hline Primigravida & 0.925 & 0.327 & 8 & 1 & 0.005 & 2.5 & 1.3 & 4.8 \\
\hline ID+DD genotype & 1.1 & 0.367 & 8.7 & 1 & 0.003 & 2.95 & 1.4 & 6.1 \\
\hline Constant & 0.36 & 0.36 & 1.01 & 1 & 0.314 & 1.4 & & \\
\hline
\end{tabular}

with preeclampsia. The $\mathrm{C}$ allele frequencies of the AT1R gene were 0.07 and 0.06 in control subjects and preeclamptic women, respectively.

We did not find any correlation between ACE and AT1R gene polymorphisms and the onset and severity of preeclampsia. Also we did not observe any differences in ACE and AT1R gene polymorphisms in different races too.

There were no significant difference in blood pressure levels (SBP and DBP) between the subjects with the different genotypes of ACE I/D polymorphism.

Multiple regression analysis, revealed that Afghan race, history of preeclampsia, gravity, and presence of $\mathrm{D}$ allele were independent risk factors of preeclampsia (Table 3).

\section{Discussion}

Preeclampsia is a multifactorial disorder that results from the interaction of multiple environmental and genetic factors. The precise cause of preeclampsia has not been determined but numerous and extensive analysis in animal models and human studies have been performed to find the relation of environmental and genetic factors with this disorder [6].

Several studies identified various candidate genes involved in high blood pressure of pregnancy and preeclampsia. Special attention has been paid to study on genes of the rennin-angiotensin system (RAS) because the synthesis of angiotensin II. Angiotensin converting enzyme converts inactive angiotensin I to vasoactive angiotensin II, therefore this enzyme is an important member of RAS and plays a key role in blood pressure regulation and electrolyte balance. Angiotensin II exerts its most actions via AT1R [12]. There are incompatible results on the relationship of ACE activity and preeclampsia. Plasma ACE activity has been associated with the insertion/deletion (I/D) polymorphism in intron 16 of the $A C E$ gene. There is evidence that DD genotype is associated with higher plasma ACE levels, whereas II genotype is associated with lower ACE levels and ID genotype with middle levels [9]. The reason for the higher ACE activity in the D allele has assumed that the I allele has a sequence like to a silencer sequence [13]. Therefore we investigated the relationship of preeclampsia to two common polymorphisms of the rennin-angiotensin system: intron 16 I/D polymorphism of the ACE gene on chromosome 17 and the A-to-C polymorphism in the $3^{\prime}$-untranslated region at nucleotide 1166 of the AT2R1 gene on chromosome 3 $[9,14]$.
In the present study we found that the ACE gene I/D genotype and allele frequencies were different between two groups and D allele was more frequent in preeclamptic women than controls. And in women with D allele (DI+DD), the risk of preeclampsia was 3.2-fold (OR, 3.2 [95\% CI, 1.7 to 5.9]; $P=0.0001$ ).

The results of our study are consistent with some but not all previous studies of ACE I/D polymorphism and preeclampsia in other countries. Zhu et al. and Zhou et al. in two different studies reported the association of ACE I/D polymorphism and preeclampsia in Chinese women and Gürdöl et al. and Choi et al. reported the association of ACE genotypes with preeclampsia in Turkey and Korea too $[13,15-17]$. Also $\mathrm{Li}$ et al. found that ACE gene I/D polymorphism were associated with the severe proteinuria and renal dysfunction seen in preeclampsia and preeclamptic patients carrying the $\mathrm{D}$ allele may be susceptible to renal dysfunction in China [18].

Mišković et al. showed a significant association between $\mathrm{D}$ allele frequency and risk of recurrent preeclampsia and preterm delivery before 34 weeks of pregnancy in Croatia [19].

Mandò et al. reported that, the distribution of ACE genotypes was different in preeclamptic women and controls in Italy. They confirmed this result in mild preeclampsia, whereas no significance was found in severe preeclampsia. They suggest that different factors may lead to mild and severe preeclampsia and ACE polymorphism playing a more important role in the mild form [20]. Also Velloso et al. suggested that the ACE DD genotype may be used as a marker for susceptibility to preeclampsia in Brazil [21], whereas Benedetto et al. revealed that the synergic effect of ACE I/D and other polymorphisms of renin-angiotensin system and eNOS may be a risk factor for preeclampsia [22].

In contrast several studies in different countries did not support the hypothesis about the association between ACE I/D polymorphism and preeclampsia. NalogowskaGlosnicka et al. [23] in Poland, Heiskanen et al. [24] in Finland, Galão et al. [25] in Brazil, Kim et al. [26] in Korea, Roberts et al. [27] in South Africa, Kobashi et al. [28] in Japan showed no association between angiotensinconverting enzyme polymorphism and preeclampsia.

Serrano et al. revealed a null association between the ACE-I/D variant and preeclampsia risk in Colombia too [29]. In a recent study Aggarwal et al. did not find any association 
between ACE gene polymorphism and hypertensive disorders of pregnancy in north India [30].

Medica et al. performed a systematic research on 10 casecontrol studies about intron $16 \mathrm{I} / \mathrm{D}$ polymorphism of ACE gene-containing 1121 patients and 1361 controls. When they compared homozygous carriers of $\mathrm{D}$ variant plus ID heterozygotes (DD+ID) versus homozygous carriers of I variant (II), the odds ratio was 1.11 (95\% CI; .91, 1.36). Whereas when they compared homozygous $\mathrm{D}$ variant carriers (D/D) versus heterozygous plus homozygous I variant (ID + II) individuals (recessive model), the odds ratio was OR 1.51 (95\% CI 1.17, 1.94); therefore they reported that single ACE I/D polymorphism did not have a major effect on preeclampsia, but statistical significance was demonstrated when the polymorphism was considered under the recessive model [31]. The results of present study showed the relation of this polymorphism with preeclampsia in dominant model.

This discrepancy in different studies is common and is due to different races, study volume, preeclampsia criteria, and other factors, however considering meta analysis study, it is more probable that the small study volume is the most important reason of this discrepancy.

In this study, we found no evidence of association between the polymorphic variants, the AT2R1 gene, and preeclampsia. The $\mathrm{C}$ allele frequency of the AT1R gene was 0.06 and 0.07 in control subjects and preeclamptic women, respectively.

There are a few studies about the association of AT2R1 polymorphism and preeclampsia. Li et al. reported that the frequency of genotypes of the AT1R gene was similar in preeclampsia and normal pregnancy [18]. Morgan et al. did not found any association between AT2R1 A1166C polymorphism with preeclampsia in UK [32]. But $\mathrm{Hu}$ et al. reported that the frequency of variants (AC, CC) of A1166C polymorphism of AT1R gene in pregnancy-induced hypertension (PIH) $(20.5 \%)$ was significantly higher than that of control subjects (7.4\%) [33]. Seremak-Mrozikiewicz et al. revealed that presence of $\mathrm{A} 1166 \mathrm{C}$ polymorphism is a risk factor for the development of PIH too [34].

In an other study Bouba et al. found that the women with preeclampsia and TT genotype of angiotensinogen had more frequently the DD genotype of ACE or the 1166C allele of AT1R than the control group and reported a significant interaction between the genes [35].

We also did not find any significant difference in rare allele's frequency of polymorphisms between three ethnic groups (Persian, Balooch, and Afghan), but we observed high prevalence of preeclampsia in Afghan women $(\mathrm{OR}=$ 2 95\% CI: 1.1-3.8). Because ethnicity have an important role in association studies, further studies with large samples must be done especially on Afghan pregnant women in these polymorphisms and other gene polymorphisms too.

In conclusion, we observed the association between I/D polymorphism of ACE gene and preeclampsia, but no relation was found between A1166C polymorphism of AT1R gene and preeclampsia. We found that Afghan race, history of preeclampsia; gravity and presence of $\mathrm{D}$ allele were independent risk factors of preeclampsia.

\section{Acknowledgments}

This research was supported by a grant from the Zahedan University of Medical Sciences and we appreciate Dr. Farzaneh Farajian Mashhsdi’s valuable advises.

\section{References}

[1] S. Grill, C. Rusterholz, R. Zanetti-Dällenbach et al., "Potential markers of preeclampsia-a review," Reproductive Biology and Endocrinology, vol. 14, pp. 7-70, 2009.

[2] D. M. Shah, "Role of the renin-angiotensin system in the pathogenesis of preeclampsia," American Journal of Physiology, vol. 288, no. 4, pp. F614-F625, 2005.

[3] B. Hocher, Y. P. Chen, S. Hügle et al., "Impact of maternal endothelial nitric oxide synthase gene polymorphisms on blood pressure, protein excretion and fetal outcome in pregnancy," Journal of Human Hypertension, vol. 22, no. 9, pp. 641-647, 2008.

[4] F. G. Cunningham, K. J. Leveno, S. L. Bloom, J. C. Hauth, D. J. Rouse, and C. Y. Spong, Williams Obstetrics, vol. 712, Mc Graw Hill, New York, NY, USA, 23rd edition, 2010.

[5] R. A. Irani and Y. Xia, "The functional role of the reninangiotensin system in pregnancy and preeclampsia," Placenta, vol. 29, no. 9, pp. 763-771, 2008.

[6] F. A. Sayed-Tabatabaei, B. A. Oostra, A. Isaacs, C. M. van Duijn, and J. C. M. Witteman, "ACE polymorphisms," Circulation Research, vol. 98, no. 9, pp. 1123-1133, 2006.

[7] E. J. Roccella, "Report of the national high blood pressure education program working group on high blood pressure in pregnancy," American Journal of Obstetrics and Gynecology, vol. 183, pp. S1-S22, 2000.

[8] A. Walfisch, M. Hallak, D. K. James, P. J. Stear, C. P. Weiner, and B. Gonik, High Risk Pregnancy Management Options, vol. 777, Saunders, Philadelphia, Pa, USA, 3rd edition, 2006.

[9] B. Rigat, C. Hubert, P. Corvol, and F. Soubrier, "PCR detection of the insertion/deletion polymorphism of the human angiotensin converting enzyme gene (DCP1) (dipeptidyl carboxypeptidase 1)," Nucleic Acids Research, vol. 20, no. 6, pp. 1433-1436, 1992.

[10] S. M. Shafiee, M. Firoozrai, S. Salimi, H. Zand, B. Hesabi, and A. Mohebbi, "Angiotensin converting enzyme DD genotype not associated with increased risk of coronary artery disease in the Iranian population," Pathophysiology, vol. 17, no. 3, pp. 163-167, 2010.

[11] M. A. Araújo, B. S. Menezes, C. Lourenço, E. R. Cordeiro, R. R. Gatti, and L. R. Goulart, "The A1166C polymorphism of the angiotensin II type-1 receptor in acute myocardial infarction," Arquivos Brasileiros de Cardiologia, vol. 83, no. 5, pp. 404-413, 2004.

[12] B. Baudin, "Polymorphism in angiotensin II receptor genes and hypertension," Experimental Physiology, vol. 190, pp. 277282, 2004.

[13] H. Choi, J. Y. Kang, H. S. Yoon et al., "Association of angiotensin-converting enzyme and angiotensinogen gene polymorphisms with preeclampsia," Journal of Korean Medical Science, vol. 19, no. 2, pp. 253-257, 2004.

[14] A. Bonnardeaux, E. Davies, X. Jeunemaitre et al., "Angiotensin II type 1 receptor gene polymorphisms in human essential hypertension," Hypertension, vol. 24, no. 1, pp. 63-69, 1994.

[15] N. Zhou, P. Yu, J. Chen, H. Huang, and S. Jiang, "Detection of insertion/deletion polymorphism of angiotensin converting 
enzyme gene in preeclampsia," Chinese Journal of Medical Genetics, vol. 16, no. 1, pp. 29-31, 1999.

[16] M. Zhu, Y. Xia, and W. Cheng, "Study on a deletion polymorphism of the angiotensin converting enzyme gene in pregnancy induced hypertension," Chinese Journal of Obstetrics and Gynecology, vol. 33, no. 2, pp. 83-85, 1998.

[17] F. Gürdöl, E. Işbilen, H. Yilmaz, T. Isbir, and A. Dirican, “The association between preeclampsia and angiotensin-converting enzyme insertion/deletion polymorphism," Clinica Chimica Acta, vol. 341, no. 1-2, pp. 127-131, 2004.

[18] H. Li, Y. Ma, Q. Fu, and L. Wang, "Angiotensin-converting enzyme insertion/deletion (ACE I/D) and angiotensin II type 1 receptor (AT1R) gene polymorphism and its association with preeclampsia in Chinese women," Hypertension in Pregnancy, vol. 26, no. 3, pp. 293-301, 2007.

[19] B. Mišković, J. Sertić, A. Stavljenić-Rukavina, and F. Stipoljev, "Association of angiotensin-converting enzyme insertiondeletion polymorphism with preeclampsia," Collegium Antropologicum, vol. 32, no. 2, pp. 339-343, 2008.

[20] C. Mandò, P. Antonazzo, S. Tabano et al., "Angiotensinconverting enzyme and adducin-1 polymorphisms in women with preeclampsia and gestational hypertension," Reproductive Sciences, vol. 16, no. 9, pp. 819-826, 2009.

[21] E. P. Velloso, R. Vieira, A. C. Cabral, E. Kalapothakis, and R. A. Santos, "Reduced plasma levels of angiotensin-(1-7) and renin activity in preeclamptic patients are associated with the angiotensin I-converting enzyme deletion/deletion genotype," Brazilian Journal of Medical and Biological Research, vol. 40, no. 4, pp. 583-5890, 2007.

[22] C. Benedetto, L. Marozio, G. Ciccone et al., "Synergistic effect of renin-angiotensin system and nitric oxide synthase genes polymorphisms in pre-eclampsia," Acta Obstetricia et Gynecologica Scandinavica, vol. 86, no. 6, pp. 678-682, 2007.

[23] K. Nalogowska-Glosnicka, B. Lacka, M. Zychma, W. Grzeszczak, and B. Michalski, " Lack of relationship between angiotensinogen gene m235t polymorphism and gene insertion/deletion (I/D-intron 16) and Pst I RFLP (P/Mintron 7) polymorphisms of the angiotensin I converting enzyme (ACE) gene and the development of H-gestosis. Preliminary results," Pol Arch Med Wewn, vol. 100, no. 1, pp. 19-26, 1998.

[24] J. T. Heiskanen, M. M. Pirskanen, M. J. Hiltunen, A. J. Mannermaa, K. R. Punnonen, and S. T. Heinonen, "Insertiondeletion polymorphism in the gene for angiotensinconverting enzyme is associated with obstetric cholestasis but not with preeclampsia," American Journal of Obstetrics and Gynecology, vol. 185, no. 3, pp. 600-603, 2001.

[25] A. O. Galão, L. H. de Souza, B. E. da Costa, R. M. Scheibe, and C. E. Poli de Figueiredo, "Angiotensin-converting enzyme gene polymorphism in preeclampsia and normal pregnancy," American Journal of Obstetrics and Gynecology, vol. 191, no. 3, pp. 821-824, 2004.

[26] Y. J. Kim, M. H. Park, H. S. Park, K. S. Lee, E. H. Ha, and M. G. Pang, "Associations of polymorphisms of the angiotensinogen M235 polymorphism and angiotensin-converting-enzyme intron 16 insertion/deletion polymorphism with preeclampsia in Korean women," European Journal of Obstetrics Gynecology and Reproductive Biology, vol. 116, no. 1, pp. 48-53, 2004.

[27] C. B. Roberts, L. Rom, J. Moodley, and R. J. Pegoraro, "Hypertension-related gene polymorphisms in pre-eclampsia, eclampsia and gestational hypertation in black South African women," Journal of Hypertension, vol. 22, no. 5, pp. 945-948, 2004.
[28] G. Kobashi, A. Hata, K. Shido et al., "Insertion/deletion polymorphism of the angiotensin-converting enzyme gene and preeclampsia in Japanese patients," Seminars in Thrombosis and Hemostasis, vol. 31, no. 3, pp. 346-350, 2005.

[29] N. C. Serrano, L. A. Díaz, M. C. Páez et al., "Angiotensinconverting enzyme I/D polymorphism and preeclampsia risk: evidence of small-study bias," PLoS Medicine, vol. 3, no. 12, pp. 2304-2316, 2006.

[30] P. K. Aggarwal, V. Jain, and V. Jha, "Endothelial nitric oxide synthase, angiotensin-converting enzyme and angiotensinogen gene polymorphisms in hypertensive disorders of pregnancy," Hypertension Research, vol. 33, no. 5, pp. 473-477, 2010.

[31] I. Medica, A. Kastrin, and B. Peterlin, "Genetic polymorphisms in vasoactive genes and preeclampsia: a meta-analysis," European Journal of Obstetrics Gynecology and Reproductive Biology, vol. 131, no. 2, pp. 115-126, 2007.

[32] L. Morgan, S. Crawshaw, P. N. Baker, J. F. Brookfield, B. F. Pipkin, and N. Kalsheker, "Distortion of maternal-fetal angiotensin II type 1 receptor allele transmission in preeclampsia," Journal of Medical Genetics, vol. 35, no. 8, pp. 632636, 1998.

[33] Y. Hu, Y. Bi, and G. Guan, "The association between A1166$>\mathrm{C}$ of angiotensin II type 1 receptor gene and pregnancy induced hypertension," Chinese Journal of Obstetrics and Gynecology, vol. 35, no. 3, pp. 136-138, 2000.

[34] A. Seremak-Mrozikiewicz, M. Dubiel, K. Drews, G. H. Breborowicz, and P. M. Mrozikiewicz, "1166C mutation of angiotensin II type 1 receptor gene is correlated with umbilical blood flow velocimetry in women with preeclampsia," Journal of Maternal-Fetal and Neonatal Medicine, vol. 17, no. 2, pp. 117-121, 2005.

[35] I. Bouba, G. Makrydimas, R. Kalaitzidis, D. E. Lolis, K. C. Siamopoulos, and I. Georgiou, "Interaction between the polymorphisms of the renin-angiotensin system in preeclampsia," European Journal of Obstetrics Gynecology and Reproductive Biology, vol. 110, no. 1, pp. 8-11, 2003. 


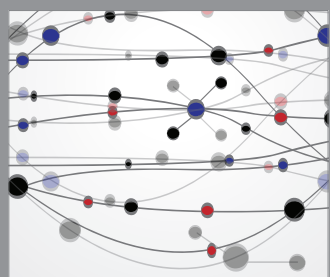

The Scientific World Journal
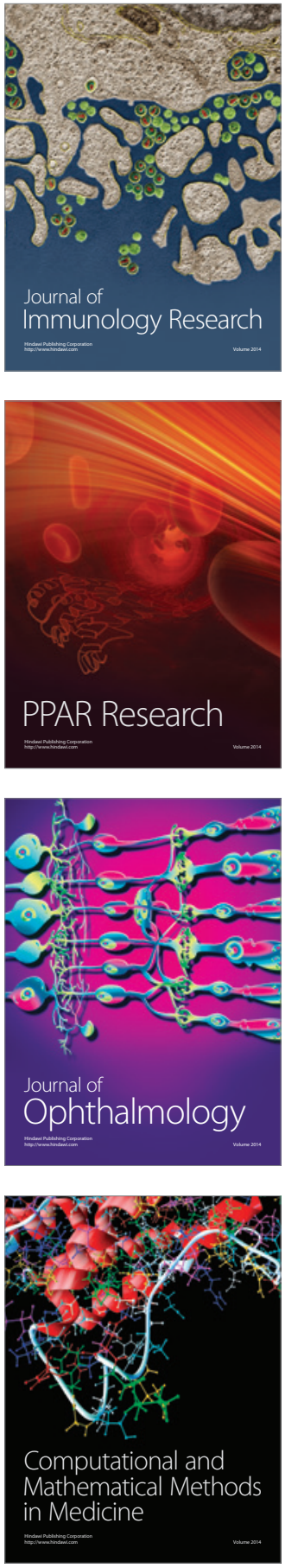

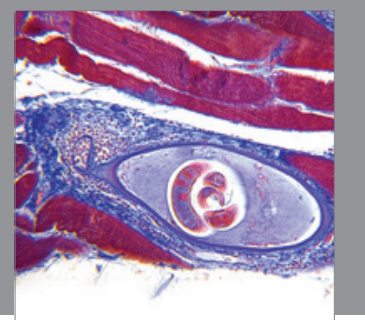

Gastroenterology

Research and Practice
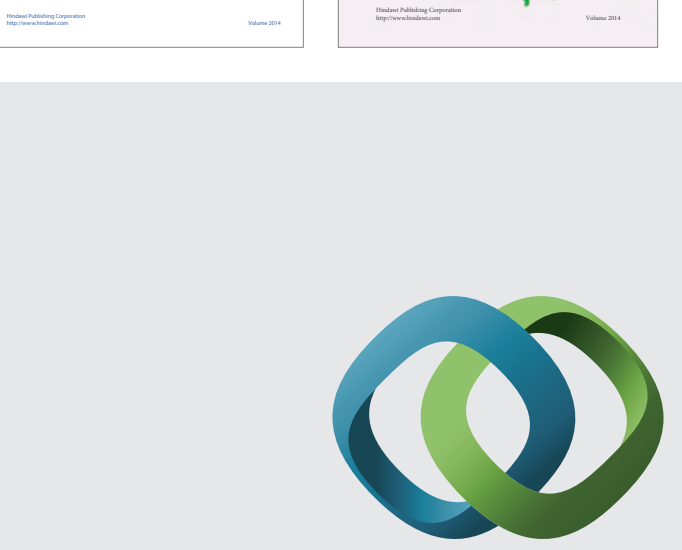

\section{Hindawi}

Submit your manuscripts at

http://www.hindawi.com
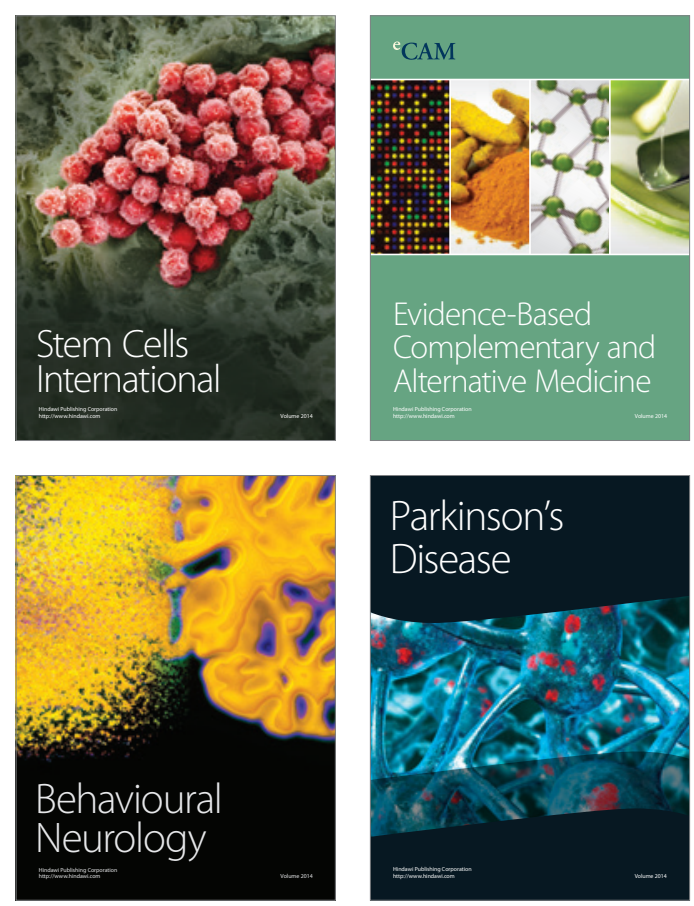

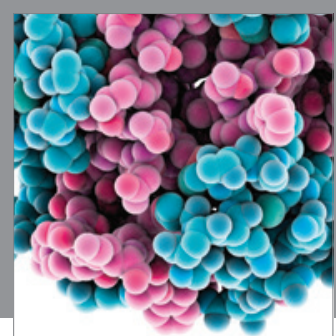

Journal of
Diabetes Research

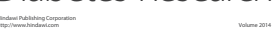

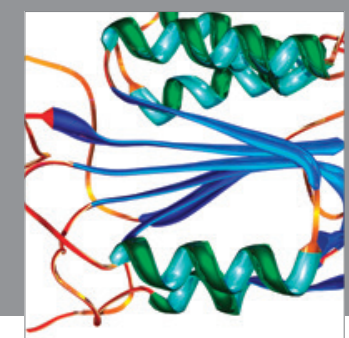

Disease Markers
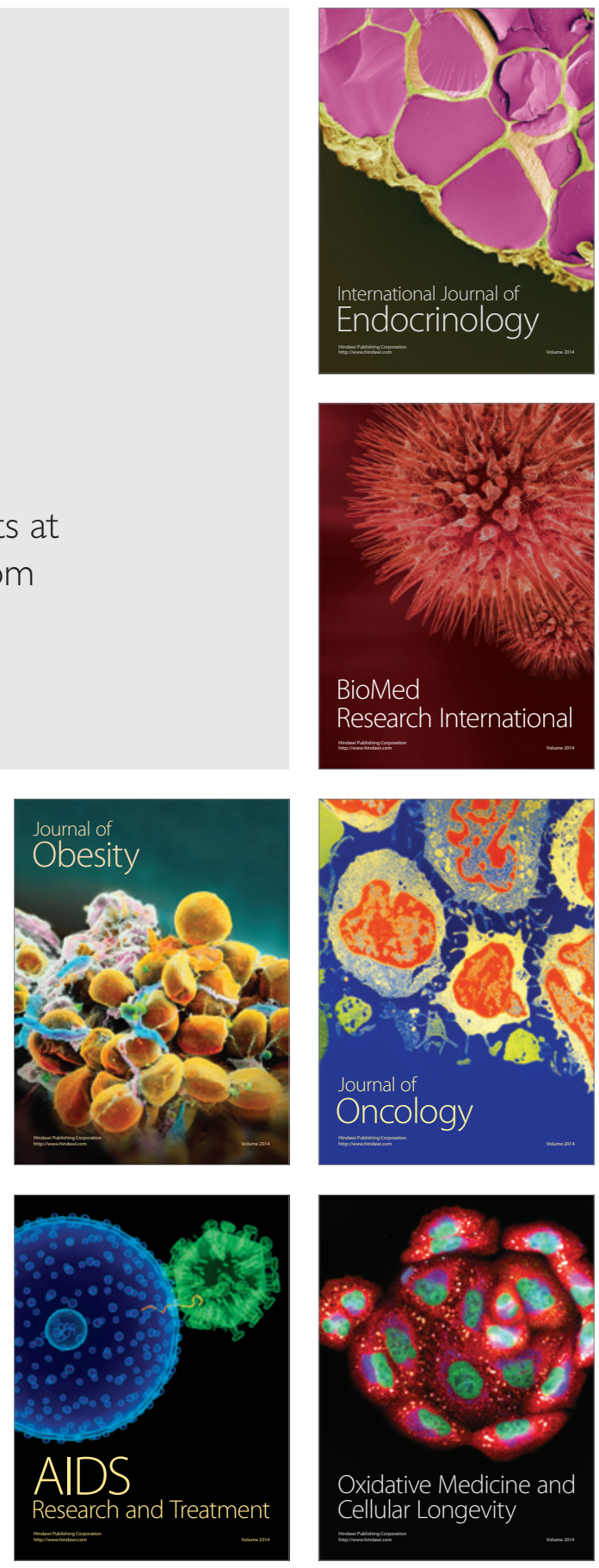